\title{
Inventing the New, Re-defining the Old: Bengali Identities in post-1947 Bangla Stories
}

\author{
Debosmita Paul \\ Ph.D. Research Scholar, Jamia Millia Islamia, India
}

\begin{abstract}
A study of the history of the Bengal region proves the fact that it is a record of creation and re-creation of several identities. These identities had constantly divided and united the people residing within the region. Class, language and region have been the major factors which have conceptualized these identities. However, the Partition of 1947 had rendered its people with identities which were communal in nature and superseded all other identities which had existed in Bengal, so far. Post-1947, the two parts of Bengal, i.e. West Bengal in India and East Pakistan in the newly created Pakistan either re-defined their earlier identities or invented new identities. The present paper attempts to trace these identities through available historical accounts and also studies them through the Bengali short stories which deal with the Partition of 1947 and Partition of 1971. The ultimate objective is to conclude that the continually redefined identities and the new invented identities have resisted the formation of identities on the basis of religion. The paper has four sections. The Introduction proposes the aim of the paper and discusses the other works done in the area in brief. The second and the third sections, titled 'Redefining the Old...' and 'Inventing the New...', trace the various Bengali identities which have existed in the region through historical accounts and by analyzing the Bengali short stories based on the Bengal Partitions of 1947 and 1971.
\end{abstract}

Keywords: Bangladeshi literature, Bengali literature, Indian Literature in English Translation, Partition studies, Short Stories

\section{Introduction}

The history of Bengal has been a record of creation and re-creation of several identities which have divided as well as united the people residing within the region. These identities have been formed on the basis of class, language and region. However, the Partition of 1947 rendered its people with identities which were communal in nature and superseded all other identities which had existed in Bengal, so far. The post-1947 situation in the divided Bengal region is also a potent field when one studies the chronological account of the several identities existing among the people of Bengal. The situation in post-1947 Bengal becomes an interesting area of study as one observes a re-definition of identities which had been subdued due to the Partition as well as invention of new identities. Debjani Sengupta's anthology Mapmaking: Partition Stories from Two Bengals collects several Bengali short stories about the Partition of 1947 from Bangladesh and India. In the 'Afterword' to the anthology, she discusses the creation of the udbastu or refugee class in West Bengal. She calls the entire genre of writings about this class as 'colony fiction'. Bashabi Frazer in the introductory note of her anthology Bengal Partition Stories talks about the resistance that communalism faced from the Bengalis masses even when the Partition riots were brewing in Bengal. Frazer, in her analysis of the collected Bengali stories also depicts the angst of the refugees in the post-Partition times. The years dealing with East Pakistan's War of Independence is well represented through the collection of Bengali short stories by Niaz Zaman. Her anthology titled Fault-Lines depicts how the men and women in East Pakistan forged new identities in order to discard their communal identities, which was responsible for the Partition of 1947. Her collection of stories by the likes of Selina Hossain, depict the how linguistic identity became the basis for the creation of a new nation and the occurrence of another Partition. Historical accounts and analysis have also discussed the udbastu identity and the formulation of an identity of the basis of a common language. Sujata Ramachandran and Ritu Menon talk about the torturous experiences of the udbastu men and women. A. K. Sur in his book History and Culture of Bengal traces the history of Bengali race since the ancient times. Dipesh Chakravarty discusses the formation of the ghoti bangal 'proximities' in West Bengal which have divided the people for long. However, none of the analyses done so far, trace and analyze these identities simultaneously in order to study the changes that the region went through as a result of the Partitions of 1947 and 1971. The present paper attempts to trace the Bengali identities which came into existence in the post-Partition period through the available historical accounts and through the accounts available through the Bangla stories. It also attempts to establish how some of the new identities formed during the Partition are a re-definition of the older identities and how some of them are invention of a new identity. 


\section{Re-Defining the Old....}

One of the major impacts of the Partition was the large scale migration of the people from across the border. In contrast to the Western border, the Eastern border of India saw a slower and a longer migration process. Infiltration from East Pakistan continued till the 1970s. Sujata Ramachandran in her article "Of Boundaries and Border Crossing: Undocumented Bangladeshi 'Infiltrators' and the Hegemeony of Hindu Nationalism in India" estimates that in 1960s and early 1970s, around nine million Hindu Bengali refugees migrated to West Bengal, Bihar, Tripura and Assam. While the period immediately after 1947 saw Hindus and Muslims crossing the borders in order to settle down in the country which the Partition process had chosen for them, the later infiltrations were due to a political upheaval which was spreading its wings in East Bengal. In the wake of the rise of Bengali nationalism in East Pakistan, the West Pakistani military unleashed a cruel attack on the Bengalis, especially the Hindus of East Pakistan in order to crush the nationalist movement, who were forced to flee to the Indian part of Bengal. The journey across the border was perilous and traumatic for the refugees. "Refugees from both communities were vulnerable to violent attacks, resulting in the separation of families, abduction of women and the orphaning of children." Their peril although did not end there. They faced an anti-immigrant sentiment from the indigenous people of their newly adopted land, along with their own struggle to establish their new identity. The Hindu immigrants from East Pakistan faced discrimination from their West Bengali co-regionalists. The immigrant women, as described by Ritu Menon, were treated as if they were impure and polluted by Muslim men and the children of the rehabilitated women were looked upon as born of "wrong", sexual union.

Amongst such allegations and discriminations, the feud between the indigenous occupants of Indian Bengal and the immigrants grew bitter as the two communities were competing for job, food and shelter. The East Pakistani Hindu was rendered with the identity of an "udbastu", a refugee and relegated to a marginal position amongst their Bengali counterparts in West Bengal. This new identity was in actuality a renaming of a previously existing identity in the Bengal region. The ghoti-bangal conflict, in the post-partition era, was visible in the form of the refugee-indigenous citizen conflict in West Bengal.

The ghoti and bangal identities have divided the people of Bengal since the ancient times and continued to be a more important a distinction for the Bengalis than any other until the Partition made religious identity a more important factor. The ghoti-bangal conflict can be traced back to ancient Bengal when the Janapadas came into existence in Bengal. Various political and economic developments in the region made the different tribes or janas create unified broader combinations to form Janapadas. Among the Janapadas, Gauda, Kamarupa, Pundra and Varendra lay in the north, Radha and Suhma in the west and Vanga, Vangala, Samatata and Harikela in the east. The presence of geographical barriers also contributed to the creation of separate Janapadas. The hilly areas in the north-west of Bengal and the delta region of the east which has numerous rivers were cut-off from the rest of Bengal. In these areas, people developed indigenous cultures and maintained separate identities.

A history of conflicts between these Janapadas has been recorded in several social and religious treatises of the region. The genealogical books of the Bengali ghatakas (match-makers) known as Kulasastras, Kulagranthas, and Kulapanjikas, are a record of the conflict between the Brahmans of Varendra and Radha. The Janapadas developed their indigenous customs over a period of time and eventually marriages outside the respective Janapadas were not preferred.

Many authors have described the social behaviour and customs of the people of these Janapadas though most often these accounts are prejudiced. In the second act of Krisnamisra's play Pravodhacandradaya, there are some indirect remarks that the Brahmans of southern Radha also known as Suhma were arrogant and vain. Another poet Dhoyi, praises the people of Suhma, and speaks of "Cultured Suhma"' . In Rajasekhara's Karpuramanjari the women of Harikela are highly praised and said to be superior to the women of Radha and Kamarupa.

The advent of the Muslims happened in Bengal around the Twelfth and Thirteenth Century A.D., when Mohammad Bukhtyar Khilji decided to reside at Lakshmanavati or Gauda. They occupied the western and the northern parts of Bengal, while the eastern parts remained under the Hindu rulers for about a century or more. This gave rise to the long-drawn wordy conflict between the people of the eastern parts, the Bangals and those of the west, the Ghotis regarding the superiority and the pristine nature of their respective cultures. The struggle for survival in the post-partition era made the conflict between the two communities more bitter.

The conflict continued till the communally-charged riots started brewing in the region and divided the people communally just before the official declaration of the Partition in 1947. The story "Treaty" by Achintya Kumar Sengupta justifies the statement. The story is about two friends from East Bengal who come to Kolkata to earn a living, leaving their families behind. Dinonath comes from Jessore while Johurali belongs to Barishal. Johurali and Dinonath are friends in spite of their religious identity. As the narrator informs: 
Their main concern was to find two-square meals a day, one whole piece of cloth to cover themselves with, a pillow under their heads for a comfortable night's sleep. Nothing else excited them or inspired them. Except of course, opportunities for saving a paisa or two, so that they could send some money to their families in the far-away villages, or even manage a trip back, themselves. ${ }^{4}$

Their only other identity is that they are poor. They are "neighbours", inter-dependent of each other and have similar needs in life.

Religion does not divide people here, but culture and language does as Dinonath notices on coming Calcutta. This difference is significantly highlighted as the narrator informs, "As he spoke in a dialect of a faraway land, and a jargon that only close friends shared, Dinonath stirred the cream vigorously" 6 . Dinonath was using a dialect used in East Bengal. Through Dinonath's reference to East Bengal as a "far-away land", the writer illustrates the difference and distance between the Bangals and the Ghotis. The cultural identity seems to be a more important factor than their religious differences until the riots make them aware of the existence of their religion. Their friendship does go through tribulations in the wake of the communal riots until their humaneness renews their friendship.

The hardships of the refugees and the human tragedy of the Partition emerged as central concerns in the literature of the post-partition period. 'Colony fiction' as Debjani Sengupta prefers to call the literature narrating the hardships of the refugees, emerged as a sub-genre of the Bangla Partition narratives from India. According to Sengupta; "Films, short stories, novels, plays belonging to this genre explore the life of people living in refugee colonies that grew like mushrooms in around the urban centers in West Bengal"8. In these narratives the Partition of 1947 appears as a not as "the past" but is like a continuous struggle. The lives of the refugees, their daily struggle for existence, their pain and loss are in a large way a comment on the Partition. Sunil Gangopadhyay's novel Arjun (1971) presents the transformation of an economically and socially marginalised refugee boy into a leader fighting for the rights of the refugees during a property dispute between the inhabitants of a refugee colony and the landlords. Narendranath Mitra's Upanagar, Manik Bandopadhyay's Shonar Cheye Dami, Samaresh Basu's Shahider Ma, and Raghab Bandopadhyay's Saishab are some novels in Bangla which portray the trials and tribulations of the inhabitants of such refugee colonies.

Bangla short stories have also discussed similar issues. In Manik Bandopadhyay's story "In a Place and in a Land", narrates the predicament of the East Bengalis like the protagonist Narahari who were not left with much of choice after 1947 but to migrate to West Bengal despite the fact that their cultural differences made them feel like a stranger there. After the Partition this nightmare of leaving one's place and migrating to the land of the strangers became a reality for many Bengalis. The struggle of these refugees was for an identity, for acceptance in their new land as well as a struggle within themselves to embrace the land of strangers as their own and survive the memories of their displaced land. Bashabi Frazer sums up the angst present in the 'colony fictions':

For the East Bengali/East Pakistani refugee, a long life of unemployment and need, gave rise to a different kind of story - that of the endless effort to combat hunger, disease, homelessness and employment, with a resilient desire to survive and live, as Nita voices in that memorable anguished cry in Ritwik Ghatak's film, Meghe Dhaka Tara, 'I want to live!'10

Debesh Roy's (b.1917-d.2001) story "Refugee” (“Udbastu”) describes the refugees' search for an identity in their newly adopted land where they are mere strangers. This is depicted through the plight of Satyabrata Lahiri and his family. The story is set during the turbulent times of the 1950s, when a fresh inflow of refugees to West Bengal began due to the language riots in East Pakistan. Satyabrata Lahiri is jobless and earns a meager living by "selling his own ability to write English and adding up correctly" settlement. His life comes to a standstill when the local police station summons him to "prove that I am really 'myself" "12 to the Indian Union. These investigations are being carried out as a result of the Nehru-Liaqat Pact in 1952, which allowed the Muslim evacuees to reclaim their properties on their return to India. The irony is that he and everyone else in his neighbourhood has to leave his/ her family and report at the local police station to prove their identity. The identity of a person is proven on the basis of recommendation of people around him who know him. However, for people living in an alien land, it is difficult to do so. This exercise, thus, jeopardizes the existence of every individual in the colony. The identity of Anjana, the daughter of Anima and Satyabrata, is also jeopardized as a result of these absurd investigations. The investigators declare before Satyabrata that "the one you consider your child, is not your own"

The discrimination by the xenophobic West Bengalis made the refugees or the newly arrived East Bengalis hate them and this led to the renewal of the age old conflict between the ghotis and the bangals.

\section{Inventing the New...}

While the Bengalis in the Indian part were rediscovering an identity which further divided them, their counterparts in East Bengal or East Pakistan created an identity which had not existed in the region so far. Bengali Nationalism made its presence felt in 1952, with the growing demand from the Bangla-speaking community for a more prominent position for their language in the political space of Pakistan. The religious 
identity of the Bengalis, which had led to the Partition, was overcome to create an identity which was based on the cultural and linguistic commonality of the Hindu and Muslim Bengalis of Pakistan. Regional differences and differences in the various dialects and sociolects of Bangla were forgotten to invent an identity which could overcome the growing atrocities of the Urdu-speaking Muslims.

The slogans - "Joy Bangla" ("Long Live Bangladesh"), "Amar Desh, Tomar Desh, Bangladesh" ("My Country and Your Country Bangladesh"), "Tomar Amar Thikana, Padma, Meghna, Jamuna" ("Your Address and Mine, Padma, Meghna, Jamuna") - manifested the territorial and linguistic basis of Bengali nationalism. The fact that Bengali nationalism transcended religious identity and created an identity based on common language and culture is well reflected in the slogan - "Banglar Hindu, Banglar Christan, Banglar Bouddha, Banglar Musalman - Amra Sabai Bangali" ("Hindus of Bengal, Christians of Bengal, Buddhists of Bengal, Muslims of Bengal - We are all Bengalis"). In the words of Rashid, "Bengali nationalism was an anti-thesis to that of the Muslim nationalism that had created Pakistan". ${ }^{14}$

Literature in East Pakistan/Bangladesh also changed its tone which the emergence of Bengali Nationalism. From the initial celebration of a new nation and attempts to legitimize East Pakistani literature as separate from the literature from India, the events of 1952 and 1971 made the writers talk of a emergence of a Bangladeshi identity. Bangla short story writers like Shaukat Osman, Selina Hossain, Akhteruzzaman Elias and Imadadul Haq have depicted the various identities the masses have adorned as a result of the changing political and social scenario of East Pakistan in the wake of these events.

Shaukat Osman's (b.1917-d.1998) "social realist"15 story "Alefa" (published. 1981) presents the "internal schisms and dissension" ${ }^{16}$ within the Muslim society in East Pakistan. The division is between the non-Bengalis, generally called Biharis, and the Bengalis in East Pakistan who have been culturally and linguistically different. In the story, the Bengalis treat the Biharis as their "inferior" ${ }^{\text {"17 }}$. The story revolves around the wedding function of Alefa, a teenager, whose mother is her sole guardian after the demise of her father.

Alefa's depression and loneliness force her mother Maliha to get her married. Karim Saheb, an old friend of Maliha's husband and a well-wisher of the family, finds a groom for Alefa. The groom, Akil Kazmi, is a Bihari who wishes to settle in East Bengal by marrying a local girl. He works in a commercial firm with a salary of two hundred and fifty rupee. At this point in the story, the gap between the Bihari Muslims and Bengali Muslims begins to surface.

The first question which Kalim Saheb asks Maliha regarding her opinion of the groom is whether she has reservations about a Bihari groom for her daughter, "With an embarrassed expression, Kalim Saheb said, 'I hope you don't mind that he's from Bihar." "18 The embarrassment in Kalim Saheb's tone clarifies his opinion about Biharis. Kalim Saheb despises them. Maliha, on the contrary has no issues as long as the groom is a Muslim. The bitterness between the Bengalis and the Biharis comes out in the open on the wedding night. An argument between the groom's side and those from the bride's side over the bride-money turns into a conflict between the Bengalis and the Biharis. The Biharis want to impose their superiority in terms of their knowledge of the doctrines of Islam.

When the elders demand the groom to give something for the local mosque, the primary school and the graveyard which is a custom among the Bengali Muslims, the groom's side, still bitter about losing the first round, refuses to pay anything. Wasim finds it as a useless practice, "'But why do you want money for the graveyard?'... 'Have we come here to wed or to die?"' ${ }^{19}$ Ali Miyan, another elder from the bride's side protests, "You spurn the custom of Bengal?" 20 The war of words turns into a physical tussle as Bengalis feel insulted. Zahur and Ali Miyan shout at the Biharis, "Have you come here to teach us custom, you Bihari apes?"21 Even Rabbani Sheikh, who had been a supporter of the Pakistan and "who thought Muslims of the world were one nation",22 loses his patience and shouts "Kick the Bihari brutes out."24 The Bengalis get ready for a fight and the angry groom's party walks out of the wedding, ignoring Kalim's plea to both the parties to calm down for the sake of the "poor widow" 25.

Alefa's wedding is ruined due to the gap between the customs of the Bengalis and the Biharis. Rabbani Sheikh, the "old Pakistanist" ${ }^{24}$ is similar to Kamal of Rushd's Bangla novel Nongor. Kamal, a supporter of the Two-Nation Theory had assured his West Bengali boss that there would be no distinction between the Muslims of West Bengal and East Bengal in Pakistan as there can be no division between the Muslims. However, with the rise of the Bengali Language Movement, his Bengali past asserts itself and he finds himself linguistically and culturally different from the Muslims who migrated from other parts of India. Similarly, Rabbani Sheikh's belief that all Muslims of the world belong to one nation, is broken in the course of the story. He identifies himself as a Bengali who is different from the Biharis. He and his fellow Bengalis rediscover their identity which was definitely not communal.

The difference between the Bengali and the Bihari Muslims was due to the fact that they were linguistically and culturally different. The aggressiveness of the Bengalis seen in "Alefa" is a reaction against the atrocities and negligence the Bengalis were facing in Pakistan. Their language and culture were being 
destroyed by their Urdu-speaking fellow countrymen. The Biharis, who were the supporters of the West Pakistan-dominated government, faced the wrath of the Bengalis in East Pakistan.

Selina Hossain's (b. 1947), short story "Looking Back" describes the events of the February $21^{\text {st }}$ agitation. A feminist writer, Hossain, has a woman agitator, Bithi, as her protagonist in the story. It describes the role the women played in the Movement in forging the separate Bengali identity in Pakistan in 1952, which history mostly ignores.

The story begins with the news that Ashfaq and Bithi's wedding has been fixed with the consent of the parents from both the sides. Bithi, a University student, is drawn towards the Language Movement and dreams of a future where her mother tongue, Bengali, would be taught to her children. Ashfaq, on the other hand, is an English educated man who is planning to do his Ph.D. in Britain. Although a supporter of Bengali as the national language, he is not as driven towards the issue as Bithi was. "He did want Bengali to be the national language, but he didn't want anything more than that." ${ }^{26}$

Through Bithi's premonitions, the author makes her readers aware of the incidents which were to follow. Bithi has a premonition of the debate at the General Assembly after the firing incident on the $21^{\text {st }}$ of February. Bithi sees the angry Maulana Debater ask for an enquiry into the unfortunate incident, "First enquiry, then the House can meet" ${ }^{27}$ and Dhirendranath Datta, another legislator, express his anguish.Bithi hears bullet sounds in her vision.

At a meeting of the Language Movement held at Madhu's canteen in the University, Ghazi, the student leader informs the gathering about the deception of the Nazimmuddin government which had accepted Urdu as the national language of Pakistan. Amidst the slogans of "We want Bengali as the national language. We want a state for Bengali" ${ }^{28}$, the decision to commemorate $21^{\text {st }}$ February as the day of the Language Movement is taken. Bithi, who had come to attend the meeting despite her father's orders against it, has a vision of the General Assembly on the day of the fiasco. The Master Debater is seen defying the Speaker's orders and demanding that: "I don't understand your Order, I won't abide by your Order. Let the Leader of the House first go and see and come back to give a description. Then the Assembly can meet." 29

Bithi is happy to learn that her marriage and the protest are on the same day. She sees the day as the symbol of the beginning of her beautiful future. Her future life would be made beautiful by seeing her children learn Bengali language and grow up in Bengali culture, which is possible only through the success of the Language Movement. Bithi says to her friends:

"I want my married life to be beautiful, which is why I want the Language Movement to succeed. I don't want to see my Barnamala burning in front of my eyes. I don't want to see children learning

Urdu. I will forget to sing my songs. No, I won't let such a day come in my life."”30

She tells Ashfaq that she would give her children a "small, beautiful Bengali name" ${ }^{31}$ instead of the traditional Muslim name like the one her fiancé has or what her in-laws would prefer, "Ashfaq Rasul Mosammat Jahan Binte Usme Kulsum,"32.

Bithi's experiences at the procession on the $21^{\text {st }}$ of February are narrated in the form of a series of film shots. The word "-Cut" ${ }^{33}$ distinguishes one scene from another. The shots show Bithi leaving the house promising her fiancé to be back soon. They next show her arriving at the University to meet the procession. In the next scene, Toyabsaheb freezes out of surprise on seeing her daughter at the procession. Bithi avoids her father and moves forward. The police are then seen training their guns at the students. The boys' procession is, in the next shot, seen advancing towards the raised guns of the police. Bithi watches this and simultaneously sees a parliamentary debate in her vision, where the Master Debater is heard demanding an enquiry on the police firing on students. It is the same vision which she had during one of her meetings with Ashfaq. Bithi in the next scene is supposedly shot, but she does not realise it. "Her mouthful of saliva tasted like blood" ${ }^{34}$ yet she continues to move forward with the help her friend Mili. She is shown dying in the next scene. The scene describes her feelings. "The next moment it seemed as if no one was suffering. Time was talking to her." ${ }^{35}$ In the last scene, Bithi falls near a big mango tree with a poster on its trunk. The poster says "We want a nation for the Bengali language, ${ }^{, 36}$ and many students like Bithi sacrifice themselves for this dream.

The sacrifice of the students shakes the national leaders out of their slumber who unite in support of the National Language Movement. Through the story the author along with the millions of Bangladeshis revisits the historic day to remember and understand the significance of it in their lives. One can also infer that, "Looking Back" presents the shift of the East Pakistani society towards Bengaliness, or in other words, the "inclusive syncretism,37 of Bengali Muslim culture.

A large portion of Bangladeshi literature is dedicated to the period around the War of Independence. The contribution and sacrifice of the viranganas or war heroines during the 1971 Liberation War has been one of the vital themes of Bangladeshi literature. People working for the Mukti Bahini, the Pak military and the razakars along with the masses have also been depicted in this body of literature. In the genre of short stories written in Bangla by Bangladeshi writers like Afsan Chowdhury ("The Body"), Shahriar Kabir ("Jesus 1971"), and Saleha Chowdhury ("The Daughter") the experiences of the common man during the War of Independence 
have been depicted. Selina Hossain's story "Double War" is set during the War of Independence and exemplifies the manner in which Bangladeshi literature has depicted the Mukti Bahini, the razakars, the khansena and the Virangana. "Double War" depicts the fight of the Bengalis in Pakistan to assert their cultural and linguistic identity over the religious identity imposed on them by the Partition of 1947.

\section{Conclusion}

The section "Redefining the Old..." discusses how the people of the Bengal region continuously redefined their identities which were based on their cultural, linguistic and regional identities. The short stories prove the fact that the ghoti-bangal identity of the pre-Partition era was renewed as the udbastu identity in the post-Partition era in the Indian part of Bengal. Although the Partition and the resultant communal riots formulated new identities on the basis of religion which subdued the presence of other identities in Bengal, the older identities were re-discovered in the years following the Partition. The following section "Inventing the new..." depicts the formulation of a new identity on the basis of one's linguistic identity in East Bengal. The assertion of the identity of the East Pakistanis as 'Bengalis' strongly refuted the religious identity which was the basis on which East Pakistan was created. The Bengali identity resulted in the creation of a new nation Bangladesh.

The study of the Bengali stories and the Bengali identities traced in the course of this paper, therefore, proves the fact that the through the continual re-defining of the old identities and the invention of the new, the people of Bengal refuted the creation of communal identities in the region.

\section{Reference}

[1]. Ramachandran, Sujata "Of Bounderies and Border Crossing: Undocumented Bangladeshi 'Infiltrators' and the Hegemony of Hindu Nationalism in India". The Partition of the Indian Subcontinent. ed. Ritu Menon. Spec. issue of Interventions 1.2 (1999):235-253.

[2]. Menon, Ritu. "Cartographies of Nations and Identities: A Post-Partition Predicament". Editorial. The Partition of the Indian Subcontinent. Spec. issue of Interventions. 1.2(1999). 157-166.

[3]. Ray, Niharranjan. History of the Bengali People (Ancient Period). Trans. John W. Hood. (New Delhi: Orient Longman, 1994).

[4]. Sengupta, Achintya Kumar. "Treaty". "Swakhar". Trans. Sarika Chaudhuri. Bashabi Frazer.(Ed.). Bengal Partition Stories: An Unclosed Chapter (Delhi: Anthem Press, 2006) 153-158.

[5]. Sengupta, Achintya Kumar. "Treaty". "Swakhar". Trans. Sarika Chaudhuri. Bashabi Frazer.(Ed.). Bengal Partition Stories: An Unclosed Chapter (Delhi: Anthem Press, 2006) 153-158.

[6]. Sengupta, Achintya Kumar. "Treaty". "Swakhar". Trans. Sarika Chaudhuri. Bashabi Frazer.(Ed.). Bengal Partition Stories: An Unclosed Chapter (Delhi: Anthem Press, 2006) 153-158.

[7]. Sengupta, Achintya Kumar. "Treaty". "Swakhar". Trans. Sarika Chaudhuri. Bashabi Frazer.(Ed.). Bengal Partition Stories: An Unclosed Chapter (Delhi: Anthem Press, 2006) 153-158.

[8]. Sengupta, Debjani. An Afterword. Debjani Sengupta. (Ed) Mapmaking: Partition Stories from Two Bengals. (New Delhi: Srishti, 2003). 185-197.

[9]. Sengupta, Debjani. An Afterword. Debjani Sengupta. (Ed) Mapmaking: Partition Stories from Two Bengals. (New Delhi: Srishti, 2003). 185-197.

[10]. Bashabi Frazer.(Ed.) Bengal Partition Stories: An Unclosed Chapter (Delhi: Anthem Press, 2006) 32

[11]. Roy, Debesh. "Refugee". "Udbastu". Trans. Sheila Sengupta. Bashabi Frazer.(Ed.). Bengal Partition Stories: An Unclosed Chapter (Delhi: Anthem Press, 2006).. 401-416.

[12]. Roy, Debesh. "Refugee". "Udbastu". Trans. Sheila Sengupta. Bashabi Frazer.(Ed.). Bengal Partition Stories: An Unclosed Chapter (Delhi: Anthem Press, 2006).. 401-416.

[13]. Roy, Debesh. "Refugee". "Udbastu". Trans. Sheila Sengupta. Bashabi Frazer.(Ed.). Bengal Partition Stories: An Unclosed Chapter (Delhi: Anthem Press, 2006).. 401-416.

[14]. Rashid, Harun-Or. "A Move for United Independent Bengal”. History of Bangladesh: Political History. Vol I. ed. Sirajul Islam. (Dhaka: Asiatic Society of Bangladesh, 1992), 400-421.

[15]. Jamal, Osman. "Introduction". God's Adversary and Other Stories. By Shaukat Osman. Trans. Osman Jamal. (Delhi: Penguin, 1996). xi-xxxvii

[16]. Jamal, Osman. "Introduction". God's Adversary and Other Stories. By Shaukat Osman. Trans. Osman Jamal. (Delhi: Penguin, 1996). xi-xxxvii

[17]. Osman, Shaukat. "Alefa”. Trans. Osman Jamal. Image and Representation: Stories of Muslim Lives in India. Mushirul Hasan and M. Asaduddin (Eds.) (New Delhi: Oxford University Press, 2000) 261-270.

[18]. Osman, Shaukat. "Alefa". Trans. Osman Jamal. Image and Representation: Stories of Muslim Lives in India. Mushirul Hasan and M. Asaduddin (Eds.) (New Delhi: Oxford University Press, 2000) 261-270.

[19]. Osman, Shaukat. "Alefa". Trans. Osman Jamal. Image and Representation: Stories of Muslim Lives in India. Mushirul Hasan and M. Asaduddin (Eds.) (New Delhi: Oxford University Press, 2000) 261-270.

[20]. Osman, Shaukat. "Alefa". Trans. Osman Jamal. Image and Representation: Stories of Muslim Lives in India. Mushirul Hasan and M. Asaduddin (Eds.) (New Delhi: Oxford University Press, 2000) 261-270.

[21]. Osman, Shaukat. "Alefa". Trans. Osman Jamal. Image and Representation: Stories of Muslim Lives in India. Mushirul Hasan and M. Asaduddin (Eds.) (New Delhi: Oxford University Press, 2000) 261-270.

[22]. Osman, Shaukat. "Alefa". Trans. Osman Jamal. Image and Representation: Stories of Muslim Lives in India. Mushirul Hasan and M. Asaduddin (Eds.) (New Delhi: Oxford University Press, 2000) 261-270.

[23]. Osman, Shaukat. "Alefa". Trans. Osman Jamal. Image and Representation: Stories of Muslim Lives in India. Mushirul Hasan and M. Asaduddin (Eds.) (New Delhi: Oxford University Press, 2000) 261-270.

[24]. Osman, Shaukat. "Alefa”. Trans. Osman Jamal. Image and Representation: Stories of Muslim Lives in India. Mushirul Hasan and M. Asaduddin (Eds.) (New Delhi: Oxford University Press, 2000) 261-270.

[25]. Osman, Shaukat. "Alefa". Trans. Osman Jamal. Image and Representation: Stories of Muslim Lives in India. Mushirul Hasan and M. Asaduddin (Eds.) (New Delhi: Oxford University Press, 2000) 261-270. 
[26]. Hossain, Selina. "Looking Back". "Phire Dekha” Trans. Bashabi Frazer. Bashabi Frazer.(Ed.) Bengal Partition Stories: An Unclosed Chapter. (Delhi: Anthem Press, 2006). 389-400.

[27]. Hossain, Selina. "Looking Back". "Phire Dekha" Trans. Bashabi Frazer. Bashabi Frazer.(Ed.) Bengal Partition Stories: An Unclosed Chapter. (Delhi: Anthem Press, 2006). 389-400.

[28]. Hossain, Selina. "Looking Back". "Phire Dekha" Trans. Bashabi Frazer. Bashabi Frazer.(Ed.) Bengal Partition Stories: An Unclosed Chapter. (Delhi: Anthem Press, 2006). 389-400.

[29]. Hossain, Selina. "Looking Back". "Phire Dekha" Trans. Bashabi Frazer. Bashabi Frazer.(Ed.) Bengal Partition Stories: An Unclosed Chapter. (Delhi: Anthem Press, 2006). 389-400.

[30]. Hossain, Selina. "Looking Back". "Phire Dekha" Trans. Bashabi Frazer. Bashabi Frazer.(Ed.) Bengal Partition Stories: An Unclosed Chapter. (Delhi: Anthem Press, 2006). 389-400.

[31]. Hossain, Selina. "Looking Back". "Phire Dekha" Trans. Bashabi Frazer. Bashabi Frazer.(Ed.) Bengal Partition Stories: An Unclosed Chapter. (Delhi: Anthem Press, 2006). 389-400.

[32]. Hossain, Selina. "Looking Back". "Phire Dekha" Trans. Bashabi Frazer. Bashabi Frazer.(Ed.) Bengal Partition Stories: An Unclosed Chapter. (Delhi: Anthem Press, 2006). 389-400.

[33]. Hossain, Selina. "Looking Back". "Phire Dekha" Trans. Bashabi Frazer. Bashabi Frazer.(Ed.) Bengal Partition Stories: An Unclosed Chapter. (Delhi: Anthem Press, 2006). 389-400.

[34]. Hossain, Selina. "Looking Back". "Phire Dekha" Trans. Bashabi Frazer. Bashabi Frazer.(Ed.) Bengal Partition Stories: An Unclosed Chapter. (Delhi: Anthem Press, 2006). 389-400.

[35]. Hossain, Selina. "Looking Back". "Phire Dekha" Trans. Bashabi Frazer. Bashabi Frazer.(Ed.) Bengal Partition Stories: An Unclosed Chapter. (Delhi: Anthem Press, 2006). 389-400.

[36]. Hossain, Selina. "Looking Back". "Phire Dekha" Trans. Bashabi Frazer. Bashabi Frazer.(Ed.) Bengal Partition Stories: An Unclosed Chapter. (Delhi: Anthem Press, 2006). 389-400.

[37]. Roy, Asim. "Being and Becoming a Muslim: A Historiographic Perspective on the Search for a Muslim Identity in Bengal". Bengal: Rethinking History. Essays in Historiography. Ed. Shekhar Bandyopadhyay. New Delhi: Manohar, 2001. 167-230. 